\title{
Scientists attack Bush over intelligent design
}

US scientists are again on the offensive against intelligent design, an idea that many see as thinly veiled creationism. The latest round stems from remarks by President George W. Bush, who on 1 August told a small group of reporters that he thought both evolution and intelligent design "ought to be properly taught" in US schools.

Scientists and science educators cried foul almost immediately, saying that such remarks could further the notion that intelligent design is a valid scientific alternative to evolution. Many researchers felt compelled to respond, even though Bush made his comments off the cuff in an informal setting. Because of the president's status, they say, his words could be used to introduce religious ideas into science classes.

"What the president has done is give impetus to people who would like to push their side of this agenda, and that's a real problem," says Fred Spilhaus, executive director of the American Geophysical Union (AGU), one of the first groups to respond to Bush's remarks. The AGU statement carried the headline "President confuses science and belief, puts schoolchildren at risk". The American Institute of Biological Sciences, the American Physical Society and the American Astronomical Society also released statements saying that intelligent design has no place in the science classroom.

Intelligent design - the notion that certain features of living organisms are so complex that they must have been shaped by an external intelligence - has enjoyed increasing prominence among the US public, although not among scientists (see Nature 434, $1062-1065 ; 2005)$. This is despite Bush's science adviser John Marburger stating on the record that intelligent design is not a scientific theory.

Lawrence Krauss, a theoretical physicist at Case Western Reserve University in Ohio and $\mathrm{a}$ frequent speaker on evolution issues, says that all scientists should be concerned. "Make no mistake - this is not an attack on evolution, but on science," he says.

Researchers are looking for new ways to

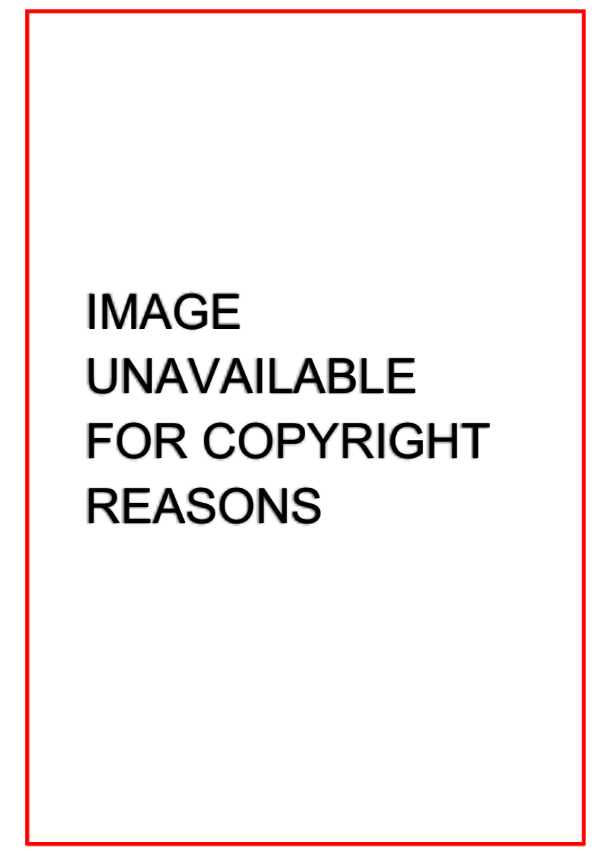

Off the cuff: President Bush said both evolution andintelligent design should be taught in schools.

fight the public-relations battle between science and intelligent design. Douglas Futurma, an evolutionary biologist at the State University of New York at Stony Brook, says he would like to see a publicrelations push mounted by an independent scientific group, such as the National Academy of Sciences.

Many experts say that scientists should get more involved in local politics -

"The president has given especially on school boards, impetus to people who of scientists and advocates of intelligent design often play out. "Scientists have to be evangelical about would like to push their side of the agenda."

explaining what science is, as well as its limitations," says Krauss.

Kenneth Miller, a biologist at Brown University in Providence, Rhode Island, adds that scientists should highlight that there is no dissent over evolution within the scientific community and that if intelligent design had scientific merit, it would have been addressed by the vigorous and open scientific process.

Virginia Gewin 